\title{
Why has sci-fi literature lost its popularity in Azerbaijan after 1990?
}

\author{
Gunel Alasgarova \\ Baku Engineering University \\ 120 Hasan Aliyev St, Khirdalan, AZ0102, Republic of Azerbaijan
}

This paper examines the reasons why science fiction works are not popular in the last decades in Azerbaijan. The focus of this research is to determine whether there is a lack of science fiction novels in the market or low-quality of existing modern novels that leads to the unpopularity in the society. The data collection methods were conducting a survey among people and several interviews of literature experts. Libraries and bookshops, as well as school literature textbooks, were observed in the search of science fiction works, as well. The survey identified the reasons for the unpopularity of science fiction and the role of authors, works, libraries, and bookshops in this trend. The findings of the survey indicate that people still read and are involved in this genre and strongly prefer world classics rather than national. While observing Azerbaijan National Library, it was found out that in modern Azerbaijan literature there are enough books in this genre, which are not properly promoted by bookshops, social media, TV programs or school textbooks. Whereas, experts in this field indicated that the newly published novels are not engaging or appealing enough to be bought by a large audience. Additionally, it would be useful to include that science fiction is losing its prestige to the fantasy all over the world, including Azerbaijan. These results partially support earlier articles that describe science fiction as an unpopular genre in Azerbaijan in the XXI century, whereas this research claims that there are readable works, which need for more advancement.

Keywords: science fiction, fantasy, Azerbaijan literature, XXI century national literature

\section{Introduction}

Science fiction, abbreviation SF or sci-fi, a form of fiction that deals principally with the impact of actual or imagined science upon society or individuals. By the beginning of the $20^{\text {th }}$ century, an array of standard science fiction "sets" had developed around certain themes, among them space travel, robots, alien beings, and time travel [19]. "Science fiction was found to be international, with science fiction creators originating in different countries and writing in a host of different languages." [22] While talking about science fiction at the end of the $19^{\text {th }}$ and early $20^{\text {th }}$ centuries, it is important to mention "The Fathers of Science Fiction" - Jules Verne in the French, Edgar Allan Poe in American, and Herbert Wells in English literatures. Their translated masterpieces like "Twenty Thousand Leagues under

(C) Alasgarova G., 2020

cc (i) This work is licensed under a Creative Commons Attribution 4.0 International License https://creativecommons.org/licenses/by/4.0/ 
the Seas", "The Unparalleled Adventures of One Hans Pfaal", "The Time Machin" influence all generations, including old and modern Azerbaijanis.

Docent at the Azerbaijan University of Languages Aybeniz Ismayilova states in her landmark book "The XX Century English Literature" [11. P. 266]: "Science fiction is a genre of fiction in which the stories often tell about science and technology of the future. Science fiction texts are often set in the future, in space, in a different world, in a different universe or dimension." This genre is based on fantastic assumptions in the field of science, including both exact and natural sciences. As it is observed, science fiction is one of the youngest genres and since the late 1940s; it has become by far the most popular all over the world.

To gain an understanding of XX century Azerbaijan literature, one must bear in mind the colonial condition of Azerbaijan under the Soviet empire. As in the majority of the nations of the Russian Empire, the influence of the northern neighbors in Azerbaijani literary and cultural life is undeniable. Therefore, it should be noted that at that time the Soviet fantasy and science fiction was more developed between the 1930s and 1980s, exhibiting in various art spheres and did not go beyond the Azerbaijani literature [2. P. 4]. “...the Soviet Union, with its political control of publishing through the Writers Union, there was, nevertheless, a thriving science-fiction community in which the Strugatsky brothers, Arkady and Boris, bestrode the landscape as Lem did in Poland, and published their imaginative fictions with intimations of antigovernment position" [9].

As it turned out, Azerbaijani science fiction writers were inspired by the writers of the Soviet Union and mostly followed their style and way. Literary critic A. Abilov [1. P. 183] fairly emphasized that Azerbaijan SF was so much connected to and dependent on Russian SF that even the word "science-fiction" inaccurately had been translated into Russian as "naucnaya fantastika" has also led to Azerbaijani translation as "elmi-fantastika", not "elmi-uydurma". At that time, science fiction works have been published in popular USSR science magazines such as "Science and Life", "Around the World", "Technique - Youth" where we can encounter Azerbaijani writers' short science fiction stories translated in Russian, as well.

Academician M. Jafarov was the first initiator who discussed science fiction genre in Azerbaijan literary criticism. In 1952, he emphasized an important influence on the perception and acceptance of science fiction novels in the development of creative imagination in children in his article called "Significance of Science Fiction in Children Education" (1952): "Science fiction plays an important role in the sustained social life and is cognitively beneficial which is necessary for humans and help them not only in childhood but also throughout their lifetime in their interpretation and support of scientific endeavors". Thus, almost all scientists admit getting inspiration from science fiction novels and stories they read in their childhood.

During 28 years of Azerbaijan independence, great attention and sources were allocated to the improvement of native literature and translation of foreign novels. "World Anthology of Fantasy" was published in 2007 by professor Zeydulla Aghayev who put great services in its publication and promotion. Based on the Azerbaijan Republic President Ilham Aliyev's order "Publication of Outstanding Literature Representatives' Works in Azerbaijani Language" [6], the "Anthology of World Science-Fiction Literature" (in two volumes) was published during 2013-2014. 
As stated by I. Sariyeva [17], "since the independence of Azerbaijan, works in science fiction genre are less encountered. Although there were a lot of novels, short stories on that genre back in the 1970s, now, for authors, it has become hard to write and even harder to find readers."

In this research, a leading problem in today's national science fiction and its current position in Azerbaijani literature will be investigated. The purpose of this research is to explore the reason of unpopularity of modern science fiction works among readers in Azerbaijan compared to the XX century. The research undertakes a comparative analysis of the publication number of contemporary young science fiction writers (Nurlan Guliyeva, Farid Huseynli, Farhad Mamadov, Lala Hasanova, Reyhan Yusifgizi) with the ones (Emin Mahmudov, Namig Abdullayev, Ibrahim Huseynov, Elmira Zamanova) of the Soviet period (1950-1980). Abovementioned modern science fiction writers could present fascinating and compelling stories and their works are even welcomed in neighborhood countries (Turkey, Russia, the USA) [10]. However, they face difficulties in the mass promotion and broad readers in the motherland. As a result, only limited editions are found in some bookshops, which lead to the diminution of readers' amount.

\section{Theoretical framework and literature review}

The first example of the science fiction genre in Azerbaijani literature was Yusif Vazir Chamanzaminli's "Future City" story, written in 1933. Starting from the 1950s, the Azerbaijani reader welcomed both national and foreign science fiction novels and short stories in translation enthusiastically. Some of the writers wrote in Russian for the broad auditory, like Yevgeni Voyskunsky, Genrikh Altov, Paul Amnuél, Isay Lukodyanov and, of course, Maksud Ibrahimbayov. According to the literary critic Aydinkhan Abilov, that was due to more than 200 million readers at that time [1. P. 183]. P. Amnuel (2005) who lives in Jerusalem now stated in his personal site: "After the 1960s the number of science fiction writers per population in Baku were much more compared to Moscow and Leningrad. Even Baku was the second popular city in the USSR after Moscow for publishing and selling that kind of novels at that time."

In 1964, Azerbaijan science fiction writers' works were published in the collection named "Formula of the Impossibility", professionally translated into Russian by Rafail Bakhtamov, under the guidance of Yevgeni Voyskunsky. The latter was a chairman of Azerbaijan science fiction writers' union at that time and due to his initiative novels of such writers like Stanislav Lem, Isaac Asimov, Ray Bradbury were translated into Azerbaijani as well. In that collection, along with Jewish and Russian-born SF writers', two Azerbaijani writers' - Emin Mahmudov's and Novruz Ganjali's novels were included in that collection. Emin Mahmudov himself, along with Genrikh Altov, was a member of science fiction writers' union of Azerbaijan in the 1960s [3. P. 76]. The second, "These Amazing Stars" came out with a circulation of 200,000 copies, and the third collection - "The Pole of Risk" was published in 1970. The demand for those books was huge till 1985.

The names of two prominent writers in this genre who wrote in Azerbaijani should be mentioned in national literature with the big letters are Namig Abdullayev and Emin Mahmudov. During 1955-1970, Namig Abdullayev ("The Magic 
Boy", “Adventures of Little Cyber", "The Night Lights", "The Walking Wife") and Emin Mahmudov ("Space Ship", "The Sky of the Venus is in the Fire", "Phenomenon", "Formula of Impossibility", "Symphony", "Pills from the Cloud") [15] presented their works to the large auditory. Ahmed Khaspoladov, Huseyn Ibrahimov, Gabil Ahmadov, Elmira Zamanova, Allahverdi Eminov [18] referred to science fiction genre in some works, as well. Analyzing almost all Soviet period articles, it is clear that both literary critics and writers somehow confused the notion "fantasy", "artistic fiction" and "science fiction". In his article "Life and Fantasy" E. Mahmudov (1964) explained that 'it was hard for writers to predict some technological ideas as high tech is realizing faster than books are published. Therefore, the best way to attract readers' attention was "depicting voyages in undiscovered space."

Through conducted research at Azerbaijan National Library, it appeared that, indeed, there are young writers come along every year with amazing works: Lala Hasanova, Reyhan Yusifgizi, Nurlan Guliyeva, Farid Huseynli, Farhad Mammadov.

Since 1994, there are well-written novels, short stories published by talented young writers. "War of Times", "Elects of Heavens", "Murderer Chupacabra", "Secrets of Underwater Caspian", "Seven Envoys", "Exiles of Heavens" and "Masters of Heavens", "Collision", "Selected Skies” by Lala Hasanova (Elizabeth Tudor) were published in Russian in the USA. Jewish-Azerbaijani origin Elizabeth Tudor is a science fiction, horror, mystery and adventure writer and her books can be bought in Amazon.com. Although she is a successful writer and a member of Azerbaijan Writers' Union since 2002, her works can be found almost none of the bookshops.

Reyhan Yusifgizi's science fiction novel "The Green-Eyed Girl" was a laureate of a children's book competition in Turkey in 2009 and published in Ankara. The "Captives of Time" science fiction novel also won the sympathy of the broader readers in 2014 where. Her work "My Friend Mimi" appeared to be the bestseller child science fiction book, according to "Uc Alma" (There Apples) publishing house.

Farhad Mammadov, young science-fiction, horror author published "The Neurotron Project", "Ten Years in the Cellars", "Sundowning Diary", "Project Bolero".

Nurlan Guliyeva's "The Mysterious Universe", Farid Huseynli's, "The Tears of the Time" science-fiction novels were newly published, but not so well promoted.

Many articles have been written focusing on local SF authors and works. Majority of them are devoted to the Soviet period works and there is almost nothing on modern ones.

E. Mahmudov (1964) and M. Jafarov (1952) fairly acknowledged that science fiction novels had a great impact in children's development and strongly advised to promote this genre in the schools even 50 years ago in the 1960-1980s. A. Abilov (2004), G. Ahmadova (2014) gave a clear description of science fiction genre, depicted its history, named some nationally prominent writers of the Soviet period and stated problems in the modern literature. Ahmadova together with R. Omarov (2003) and R. Soltanova (2010) dedicated their whole thesis to the investigation of this genre, praising national writers and compared them with world colleagues. I. Sariyeva (2017) and P. Amnuel (2005) wrote an article about old and modern SF in Azerbaijan and claimed that nowadays it is in its critical point. Fo- 
reign journalist Awet (2016) carries the same idea and insists that SF is not for the XXI century. None of them investigated the real problem of a small number of new writers and unpopularity of their works for the last 20 years.

Another research was done by Z. Aghayev (2007) who conducted research of American SF authors, translated some works and published a book including Azerbaijani writer Namig Abdullayev's "Flower of the Far World". V. Ismayilov (2015) and website of Elizabeth Tudor can give us some information on new local successful writers. A. Ismayilova (2014) allocated one chapter to world SF in her landmark book. Foreign authors like D. D'Ammassa (2005) and B. Sterling (2018) gave vast information about this genre and their work can be extremely useful for scholars. All of these prior studies indicated the same that SF genre is vitally important for all generations and there are some classical SF works that should be read by everyone. All in all, none of the articles published till now, mentioned about the state of modern science fiction genre and the reasons for their unpopularity among the youth.

\section{Methodology}

The aim of this study is to find out the actual condition of modern science fiction in native literature. For this analysis, both quantitative content and qualitative thematic analysis were carried. The research question is, "Why has Sci-Fi literature lost its popularity in Azerbaijan after 1990?" The hypothesis is that - although there is some amount of works in this genre, they are not well promoted to the large auditory. The new generation does not have any fascination with it, because neither libraries nor schools or mass media advertise them.

A short survey (eleven questions) was designed to gather information about whether people were aware of science fiction, how often people read science fiction, their preference (national or foreign science fiction), etc. To this purpose, the survey included multiple questions on writers and their works. The survey questions were both closed, employing 5-point Likert-type scales, and open-ended questions prompting free text responses. The survey was written in Azerbaijani and English using Google Form and participants answered the questions online. It was launched during January 2019 and the number of volunteers was one hundred. All respondents volunteered to participate; they were given a written information sheet about the research. None of the personal questions were asked and anonymity was ensured.

Data collection consisted of several interviews of literary critics and experts as well as bookshop representatives. Interviewers are professors Gorkhmaz Guliyev, Naila Sadigova, Shahin Khalili, Docent Gabil Ahmadov from Azerbaijan University of Languages, Azerbaijan State Pedagogical University, Azerbaijan University, Baku State University, representatives of publishing houses and bookshops "Ali and Nino", "Uc Alma", "Chirag", "Ganun", "Kitabkhananet") and literary critic Aydinkhan Abilov. The aim of the interview was to seek answers to the following questions:

1. What is the genre preference of modern readers?

2. What kind of science fiction books do you have in your bookshop?

3. Do you have any modern science fiction writers' works in your shop?

4. Why do people buy and read less science fiction works nowadays? 
For this research, seven school literature textbooks were analyzed as social artifacts. It is a very effective method to view problems from different perspectives to arrive at real solutions that may be helpful and appropriate in the local case. The limitations are: the findings are not suitable for generalization since this investigation concerns only one literature genre and due to the limited time, it was possible to contact several bookshops and interview few experts. Online survey respondents were also limited and can not reflect an attitude of a broader segment of an Azerbaijani population who are not regular users of the Internet or are not followers of social media. That is why the results cannot be determined whether the science fiction genre is unpopular in all Azerbaijan regions or among modern generation.

\section{Results}

The units of analysis in this research paper is individual people - readers. Thus, a survey questionnaire has been administered to collect original data for describing people's interest and preference in reading. Conducted nonprobability sampling was sufficient vehicle for measuring reading habits and awareness of SF genre. As the survey closed, a total of 100 survey responses were collected. The questions were not mandatory, so there are variations in response numbers, as shown in the figures.

The survey demonstrated that people were aware of the science fiction genre, although they are well acquainted with foreign samples. "Have you ever read science fiction stories?" (Figure 1) and "Do you prefer?" (Figure 2) present the following results.

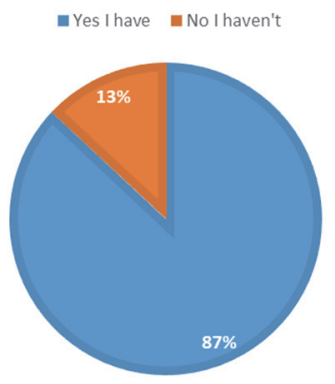

Figure 1. Have you ever read science fiction stories?

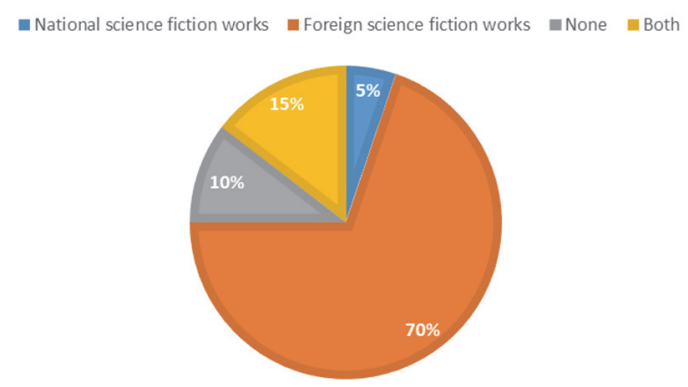

Figure 2. Do you prefer?

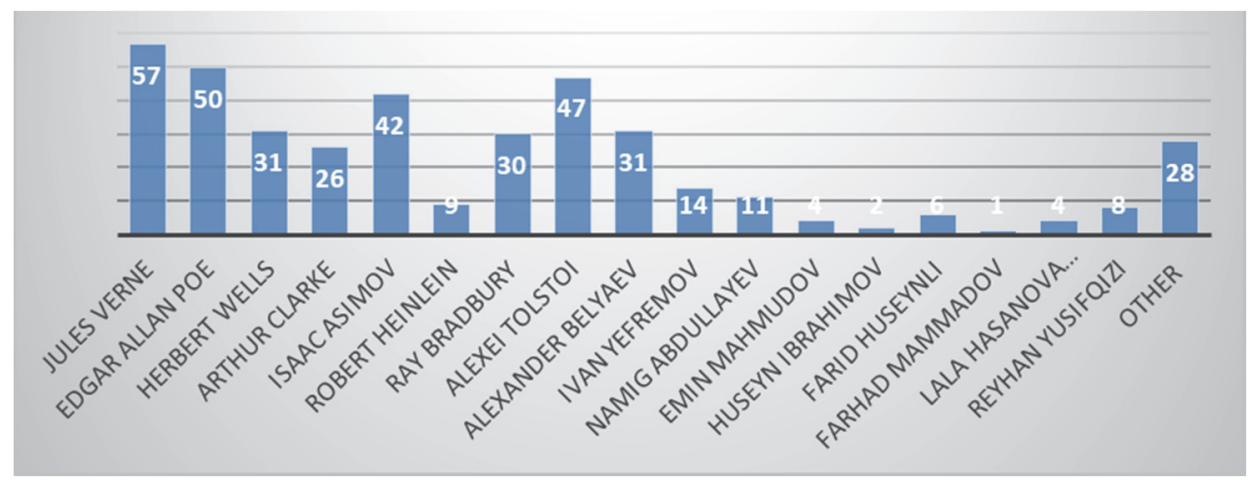

Figure 3. Which writers do you know? 
There was a strong positive response to the question about awareness of this genre $(87 \%)$. Responses to the question on preference (Figure 2) were against national SF (5\%) and for foreign SF (70\%) which is almost great. The following info (Figure 3) also correlates with Figure 2 and proves that respondents mostly know world classic SF writers.

One of the claims of the modern SF experts was that nowadays people not only in Azerbaijan, but all over the world prefer to watch SF movies rather than to read SF novels. As A. Roberts wrote: “...it seems clear that today the most groundbreaking, the most exciting and also the most popular SF takes the form of visual narrative. Was I bold enough to hazard prediction, it would be that this will increasingly become what SF is: cinema, TV, computer games (with an increasingly narrative component) and graphic novels" [16. P. 343]. Unfortunately, there isn't any new movies or programs based on newly published SF novels in national TVs. According to the survey results (Figure 4), it appeared that it is not the reason of unpopularity of national SF works, so that survey respondents prefer both to read and watch SF (48\%).

Even in libraries, SF genre is not propagating properly, that Figure 5 can show.

घTo read science fiction novels $\square$ To watch science fiction movies $\square$ Both $\|$ None

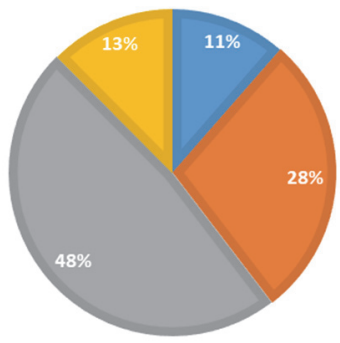

Figure 4. Do you like?

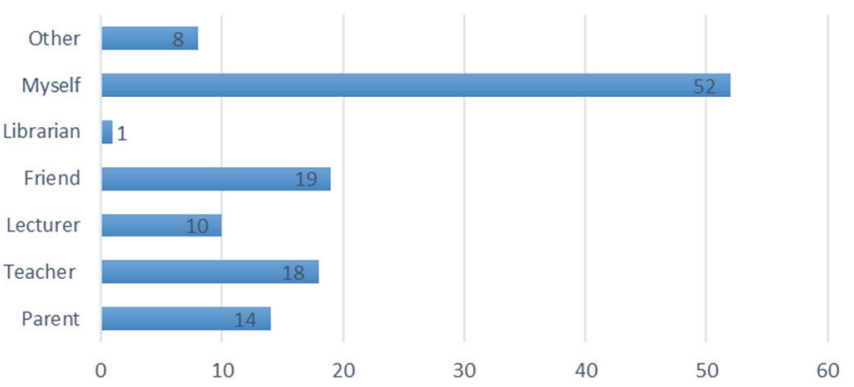

Figure 5. Who advise you to read SF books?

As it can be observed, respondents admitted that they themselves decided to read SF novels. Also, almost all respondents think that science fiction inspires scientific comprehension and opens the reader to the new ideas. This result correlates with the preliminary findings from an online survey conducted by Ch.B. Menadue and S. Jacups (2015) where there was a very positive response (92.7\%) to the suggestion that sci-fi opens readers up to new ideas in general. From the same survey it is obvious that almost all (96.3\%) respondents started reading science fiction 
before age 20 which is interesting evidence that this genre is for development of mindset of youngsters.

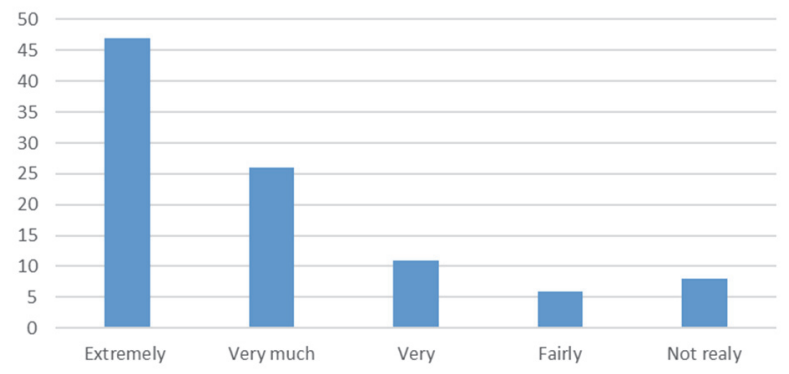

Figure 6. Do you think SF opens you up to new ideas?

There was a very strong positive response to the SF novels that had been adapted to the films like "Amphibian Man" (50\%), "Star Wars" (31\%), "War of the Worlds" (30\%), "The Time Machine" (45\%), "Invisible Man" (43\%). The most known national works are "Tears of the Time" (Zamanın göz yaşları, 2017) (9\%), "The Mysterious Universe" (Sirli Kainat, 2010) (8\%), "The Sky of the Venus is in the Fire" (Veneranın gözləyi od içindədir, 1960) (7\%) and "My friend Mimi" (Dostum Mimi, 2017) (6\%). It can also display that among four old and four modern national SF works, respondents have selected options with present time works.

There were two open-ended questions in the survey, where accumulated engrossing answers. One of them was "What is the main difference between national science fiction and foreign science fiction works?" with 14 answers. Some of them are interesting and would be useful for further research. One respondent wrote: 'I think native writers' style is way much weaker than foreign writers. In the past, Azerbaijan had many prominent writers but today only a few of them left. I think their word choice and storyline are not so effective." The other one is: "The main difference is that foreign science fiction works seem focused on more sophisticated technology-based stories than national science fiction works." Most of the respondents praised foreign science fiction, explaining it as more credible, full of relating facts, complicated characters and details. It is for sure that world-famous SF novels cannot be compared with national. The main reason is "not having a strong high technological foundation and space exploration stations" as Z. Aghayev stated [2. P. 6].

The second open-ended question was "What would you advise our writers?" and collected 36 replies. "To develop their storylines and writing style. Especially our young writers are so excited about writing and publishing a book, so I think they do not spend much time on writing period", "As for me, I want to see a science fiction work in Azerbaijan that I will like more than I like Professor Dowel's Head", "I do not read local writers because I do not know them. If they advertise their work, I could read some of them", "I would love them to be more seen or advertise their work so they can reach more people. Secondly, I'd advise to work on the sci-fi genre, write more, publish more", "Write in a way that a reader starts to questions whether it can be real or not; not like it is not real that's it! In order words, I suggest being more convincing", "To be aware of the science of the predictions 
they make in the stories. Because while you may think that SF stories are only meant to engage public, however, it sometimes may open eyes of the scientific community for creativity and be useful for possible future discoveries" are some amazing pieces of advice for local writers. All in all, responses show that people are not acquainted with modern SF books at all.

The face-to-face interviewing was another method of collecting data for this research. Experts, professors of world literature and people who are in this field more than 50 years were addressed with one question: How do you evaluate modern science fiction in Azerbaijan?

According to the Doctor of Philological Sciences, one of the first world science fiction researchers in Azerbaijan, who published "Modern American Science Fiction. Problems of the Method and the Genre (based on the works of A. Azimov, R. Bradbury, C. Simak)" Prof. Naila Sadigova: "Science fiction genre is perceptive and insightful creation that requires a great deal of research, innovation, and imagination. I consider that SF is for intellectuals and it is very popular among clever young people. Unfortunately, most of the modern writers prefer not to bother themselves with science and write only fantasy, love stories, and soap operas" (personal communication, November 5, 2018).

Doctor of Philological Sciences, Prof. Gorkhmaz Guliyev (personal communication, December 27, 2018) admitted that he used to read science fiction stories enthusiastically and followed all new publications. Unfortunately, it lost its actuality, prestige, interest and gave way to the fantasy not only in Azerbaijan but also over the world. XXI century is not the best time for SF. Supporting Prof. Guliyev's claim, it appeared that "the magazines, from the venerable Fantasy and Science Fiction to the once-dominant Isaac Asimov's Science Fiction Magazine are at astonishingly low circulation levels" [8]. "That dominance has been challenged during the last few years by the increasing popularity of fantasy fiction" [7. P. 5]. In order to prove this claim, one example can be given as well. One of the often visited book cafes in Baku Libraff allocated two sections full of fantasy books whereas there were only three world science fiction novels ("The Time Machine", Collection of Selected Works by Isaac Asimov, and "My friend Mimi") and two anthologies that were mentioned above.

As stated by Doctor of Philological Sciences, Prof. Shahin Khalili (personal communication, November 6, 2018), great American writer Isaac Asimov's parent was a Jewish from "Red Town" municipality in Guba district of Azerbaijan. Even Isaac Asimov confirmed that fact in his dialogue with the professor Zeydulla Aghayev in 1989. But unfortunately, no one could prove it and present it to a mass audience. Connecting this claim, he said that "including Isaac Asimov, there were and are eminent writers of science fiction in Azerbaijan. The matter is only in propagating them and moving forward."

Docent Gabil Ahmadov, who can be considered two generations' science fiction writer and researcher, was purposefully interviewed (personal communication, January 4, 2019). He could give a clear picture of the old and modern SF in Azerbaijan literature. While complaining about neglect both to this genre and him, he mentioned that no one wants to deal with or learn it. The main reason, as he sees, is lack of promotion of this genre by the state. He expressed that although he wrote 
several books in science fiction genre, none of them was included to the program at the Baku State University. Students simply do not know about the existence of those works. According to Ahmadov, he took courses in various developed countries and in all of them he encountered that science fiction novels had been included in the curriculum. It would be useful to mention Gabil Ahmadov's some works that he wrote before and after independence: "2143" (2010), "The Sky of the Venus is Getting Blue" (1992), "Guest from the Alien World" (1987), "The Worlds Communicate" (1987). His wife, doctor of philosophy Gulsum Ahmadova defeated her thesis on "Traditions of Science Fiction Genre in Azerbaijan Genre" (2014).

According to the words of virtual library "Kitabxananet" founder and literary critic Aydinkhan Abilov (personal communication, November 8, 2018) last 20 years Azerbaijanis do not read science fiction and it is difficult to find national literature about distant space travel, invasion of alien civilizations, cosmic mind, and so on in the libraries The main reason for that is the school and social media. As the writer and journalist mentioned, in recent years, schoolchildren don't have a lesson called "astronomy" and space ideas are not promoted in the school curriculums. There is not any single program or intellectual show about space, astronomy, and astrophysics on TVs. Neither television nor other media pay any particular attention to this field. To support Mr. Abilov, as the research artifacts, seven school literature textbooks (from year 5 to year 11) and chrestomathy were observed. It appeared to be that there is not any science fiction work or information of writers in this genre. Even in the textbook vocabulary, there is not an explanation of "science fiction" word or any note about it. Only in the textbook of year 5, the author advised reading "World Anthology of Fantasy" (2007) as an extracurricular reading. That is all school children can get about this genre from the literature lesson for 7 years. All these factors greatly influence the new generation and as a result, today, the science fiction genre is completely exhausted in national literature.

Well-known and prominent bookshops and publishing houses were interviewed via telephone. One of the biggest publishing houses representative Ms. Mehriban (Ganun Publishing House, personal communication, December 28, 2018) could clearly describe Azerbaijani readers' preferences and interests during the last five years. She informed that during book fairs people prefer to buy detective, psychological and self-developing books. People less and less chose classics or scientific books. Although teenagers and the youth are enthusiastic to buy books, they prefer foreign authors. "The main reason can be persuasiveness and modernity in them" as stated Mr. Mehriban.

"Kitabevim" (personal communication, December 28, 2018) book market representative admitted that science fiction books are less bought and the main reason is week promotion of them. In spite of that, on their own initiative, Reyhan Yusifgizi and Farhad Mammadov could present their stories in the book market.

A representative of "Ali and Nino" book store Nihat Shahverdizade (personal communication, January 17, 2019) surprised informing that people buy science fiction books if they are foreign classic SF novels. Their bestseller books are "Solaris", "I, Robot" and "Flowers for Algernon" and the main reason can be considered their writing style which easily convinces the reader. None of the modern SF writers are being sold in their shops. 


\section{Discussions}

The collected data from the survey and interviews strongly indicate that nowadays science fiction works are less being created and sold compared to old times and there are various reasons. Some of them can be eliminated and some of them are inescapable.

It appeared that there are several forward-looking science fiction writers in modern national literature. Comparing the state of old SF with new, it is obvious that the government financially supported and published collections of various stories. Collections short stories of national writers were distributed in all school libraries for out-of-class reading. Also, meetings of SF writers were constantly organized whereas none of abovementioned is applied nowadays.

Some researchers think that in XXI century science fiction writers cannot catch up with the technology. High technology is one step forward as science fiction novel publishes with the new idea. "The world is changing too quickly that the attempt to predict the future will already make the book obsolete by its publication date. To acknowledge this without confronting the difficulty, science fiction represented the inaccessible future as the technological singularity - the eventual merging of technology and biology" [5].

For the future development of the abovementioned genre, Azerbaijan needs to educate and train a generation of enthusiastic people who are ready to work and investigate in the space age. We must continue with the simplest, that is, with the translation of books by famous science fiction writers, such as Isaac Asimov, Artur Klark, Robert Heinlein, Ray Bradbury. This fascinating literature will definitely attract the attention of young people. The second is the promotion of already written national science fiction works. Those works and genre itself should be included in school textbooks. The third way is visual - some movies and TV programs should be created and demonstrated regularly.

\section{Conclusion}

The present study strongly supports the concept that the science fiction genre is very important with its new ideas, novel thoughts and methods and both writers and Azerbaijan Writers Union should do their best to promote this genre in Azerbaijan. Conducted survey and interviews could give a clear picture of today's SF in Azerbaijan. Firstly, modern generation knows a lot about world SF writers and novels and need to get acquainted with national novels in the school/university/ library, on TV programs and newspapers constantly. Here we should include both classic and modern SF works, so that survey showed none of them are well-known to the large audience. However, all expressed willingness to read compelling local SF works.

Secondly, some experts in this field condemned modern authors in poor writing style, deficient ideas and advised them to work hard on their technique. It was also mentioned that the XXI century is not for SF, rather than for fantasy and memoirs. The results indicate that SF genre itself is not popular, while people prefer to read famous foreign rather than local works. The present research examined only a few aspects of investigation to find out the reasons of the unpopularity of SF. 
Overall, this data suggests that several young writers presented interesting and attractive novels in science fiction for both elders and children during independence. They should be advertised and promoted as much as possible.

Acknowledgment. I would like to express my gratitude to the US Embassy Baku and ADA University for launching a one-year project on "Strengthening Research Capacities and Building International Partnership" aimed at enhancing research potential of Azerbaijan and building academic partnerships with U.S. Universities. I would like to thank my family who provided me with moral support and continuous encouragement. Thank you.

\section{References}

[1] Abilov, A. (2004). Fiction Fantasy: The hidden layer of Azerbaijan Literature [Bədii fantastika: Azərbaycan ədəbiyyatının gizli qat1]. Azerbaijan, 3, 182-196.

[2] Aghayev, Z. (2007). Boundless human intelligence [İnsan zəkasının hüdudsuzluğu]. World Anthology of Fantasy [Dünya Fantastika Antologiyasi] (pp. 4-11). Baku, EastWest Publ.

[3] Ahmadova, G. (2014). Ways of development of science fiction in Azerbaijan for the last half-century. Philological sciences, (2-8), 76.

[4] Amnuel, P. (2005, April 26). Those glorious sixties. Retrieved from https://amnuel. livejournal.com/5760.html (accessed: 09.12.2018).

[5] Awet. (2016). The Decline of Science Fiction. Aesthetics, History of Ideas, Literature, Philosophy. Retrieved from http://www.hyperboreans.com/heterodoxia/?p=1295 (accessed: 10.12.2018).

[6] Publication of Outstanding Literature Representatives' Works in Azerbaijani Language, Ilham Aliyev's order No. 2354. (2007, August 25). Azerbaijan journal.

[7] D'Ammassa, D. (2005). Encyclopedia of science fiction. New York.

[8] Fantasy \& Science Fiction. (2019). Retrieved from https://www.sfsite.com/fsf/blog/ forum/topic.php?id=1170071 (accessed: 26.01.2019).

[9] Gunn, J. (2010, May-June). Science fiction around the world. World Literature Today, 84(3), 27-29.

[10] Ismayilov, V. (2015, January 28). An Azerbaijani woman who conquered Russian literature [Rusiya adabiyyatın foth edan azarbaycanlı qadın]. Retrieved from https://archive.is/ Yt9vi\#selection-593.0-593.48 (accessed: 21.12.2018).

[11] Ismayilova, A. (2014). Science fiction genre. The XX century English Literature. Baku: Mutarjim Publ.

[12] Jafarov, M. (1952). The significance of science fiction works in children's education [Uşaqların tərbiyəsində elmi fantastik əsərlərin əhəmiyyəti]. Revolution and Culture, 9, 128-143.

[13] Mahmudov, E. (1964) Life and Fantasy. Literature and art [Әdəbiyyat va incasanət. Hayat va fantastika].

[14] Menadue, Ch., \& Jacups, S. (2018, April - June). Who reads science fiction and fantasy, and how do they feel about science? Preliminary findings from an online survey. SAGE Open, 1-12

[15] Omarov, R. (2003). Science fiction in the US and Azerbaijan literature (based on Isaac Asimov's and Emin Mahmudov's works) [XX asr ABŞ vo Azarbaycan adabiyyatında elmi-fantastik janr Ayzek Azimov vo Emin Mahmudovun yaradıcılığl asasında] (PhD thesis) (p. 22). Baku.

[16] Roberts, A. (2006). The History of Science fiction. Macmillan, New York.

[17] Sariyeva, I. (2017). In our contemporary literature, the science-fiction genre crisis continues [Müasir ədəbiyyatımızda elmi-fantastik janr böhranı davam edir]. Azerbaijan In- 
formation Centre. Retrieved from http://azim.az/edebiyat/3500-muasir-dbiyyatimizdaelmi-fantastik-janr-bohrani-davam-edir.html (accessed: 01.12.2018).

[18] Soltanova, R. (2010). Science fiction genre in Azerbaijan literature [Azarbaycan adobiyyatında elmi-fantastik janr] ( $\mathrm{PhD}$ thesis) (p. 27). Baku.

[19] Sterling, B. (2018). Science fiction: Literature and Performance. Retrieved from https://www.britannica.com/art/science-fiction (accessed: 21.11.2018).

[20] Thomas, P.L. (2013). Science Fiction and Speculative Fiction: Challenging Genres. Furman University, Greenville, USA.

[21] Tudor Elizabeth. Retrieved from http://elizabeth-tudor.com/products.php (accessed: 21.11.2018).

[22] Wells, E. (2013). Science fiction as a worldwide phenomenon: A study of International creation, consumption and dissemination. COINs $13-4^{\text {th }}$ International Conference on Collaborative Innovation Networks, August 12-14, 2013, Santiago de Chile, Chile. Retrieved from https://ui.adsabs.harvard.edu/abs/2013arXiv1308.1292W/abstract (accessed: 26.01.2019).

Article history:

Received: 2 November 2019

Revised: 15 November 2019

Accepted: 1 December 2019

\title{
For citation:
}

Alasgarova, G. (2020). Why has sci-fi literature lost its popularity in Azerbaijan after 1990? RUDN Journal of Studies in Literature and Journalism, 25(1), 68-81. http://dx.doi.org/ 10.22363/2312-9220-2020-25-1-68-81

\section{Bio note:}

Gunel Alasgarova, Candidate of PhD of World Literature, Baku Engineering University; teacher, Oxbridge Academy. E-mail: gunel_i@yahoo.com

\section{Почему научно-фантастическая литература потеряла свою популярность в Азербайджане после 1990 года?}

\author{
Г. Аласгарова \\ Бакинский инженерный университет \\ Азербайджанская Республика, AZ0102, Хырдалан, ул. Гасана Алиева, 120
}

\begin{abstract}
В статье рассматриваются причины, по которым научно-фантастические произведения в последние десятилетия не пользуются популярностью в Азербайджане. Цель данного исследования - определить, что приводит к непопулярности жанра в обществе: недостаток научно-фантастических романов на рынке или низкое качество современных произведений. Методы сбора данных заключались в проведении опроса населения и нескольких интервью с экспертами по литературе. Поиски научно-фантастических произведений проводились в библиотеках и книжных магазинах, также на предмет наличия произведений данного жанра были изучены школьные учебники литературы. В ходе
\end{abstract}


опроса были выявлены причины непопулярности научной фантастики и их зависимость от авторов, произведений, библиотек и книжных магазинов. Результаты опроса показывают, что люди все еще читают и вовлечены в этот жанр, но больше предпочитают мировую классику, а не национальную. Выяснилось, что в современной азербайджанской литературе достаточно книг в жанре научной фантастики, которые должным образом не продвигаются книжными магазинами, социальными сетями, телевизионными программами или школьными учебниками. В то же время эксперты в этой области отметили, что недавно опубликованные романы недостаточно привлекательны, чтобы покупаться большой аудиторией. Кроме того, было бы полезно отметить, что научная фантастика теряет свой престиж перед фантастикой во всем мире, в том числе и в Азербайджане. Эти результаты частично подтверждают более ранние статьи, которые описывают научную фантастику как непопулярный жанр в Азербайджане в XXI веке, в то время как настоящее исследование утверждает, что есть читаемые произведения, которые нуждаются в большем продвижении.

Ключевые слова: научная фантастика, фэнтези, азербайджанская литература, национальная литература XXI века

Благодарности. Выражаю признательность Посольству США в Баку и Университету ADA за запуск годичного проекта «Укрепление исследовательского потенциала и построение международного партнерства», направленного на повышение исследовательского потенциала Азербайджана и налаживание академического партнерства с университетами США. Благодарю свою семью, которая оказала мне моральную поддержку и постоянное поощрение. Спасибо.

\section{История статьи:}

Дата поступления в редакцию: 2 ноября 2019

Дата принятия к печати: 1 декабря 2019

\section{Для цитирования:}

Alasgarova $G$. Why has sci-fi literature lost its popularity in Azerbaijan after 1990? (Почему научно-фантастическая литература потеряла свою популярность в Азербайджане после 1990 года?) // Вестник Российского университета дружбы народов. Серия: Литературоведение. Журналистика. 2020. Т. 25. № 1. С. 68-81. http://dx.doi.org/10.22363/ 2312-9220-2020-25-1-68-81

\section{Сведения об авторе:}

Аласгарова Гюнель, кандидат филологических наук, Бакинский инженерный университет; преподаватель, Академия Оксбридж. E-mail: gunel_i@yahoo.com 